\title{
Monetary Policy Transmission Through the Rate Channel in Some Countries in ASEAN
}

\author{
Nguyen Thi Quynh Dung ${ }^{1}$, Pham Thi Ha $\mathrm{An}^{1}$ \\ ${ }^{1}$ Van Lang University, No. 45 Nguyen Khac Nhu Street, Co Giang Ward, District 1, Ho Chi Minh City, Vietnam \\ Correspondence: Pham Thi Ha An, Van Lang University, No. 45 Nguyen Khac Nhu Street, Co Giang Ward, District 1, \\ Ho Chi Minh City, Vietnam.
}

Received: December 9, 2019

Accepted: February 5, $2020 \quad$ Available online: February 21, 2020

doi:10.11114/aef.v7i2.4729

URL: https://doi.org/10.11114/aef.v7i2.4729

\begin{abstract}
Using a quantitative regression of table data through FEM and REM models, the study has measured the extent and direction of exchange rate impacts on the economic growth of five ASEAN countries namely, Vietnam, Indonesia, Singapore, Philippines, Malaysia, in the period of 1985-2015. The estimation results show that for every $1 \%$ rise in the real exchange rate, the multilateral force will have a positive impact, since the speed of economic growth of five countries increased by $2.09 \%$. This result is consistent with some previous studies, especially in some developing countries. Further, the thesis has assessed the exchange rate policy in Vietnam and analyzed the situation. As a result, the authors have made some recommendations for exchange rate policy. The recommendations focus on the State's intervention in adjusting the exchange rate and pay attention to the real exchange rate for policy evaluation. The recommendations of the thesis are consistent with the actual situation in the five ASEAN countries in order to stabilize economic growth.
\end{abstract}

Keywords: transmission, rate channel (ERC), FEM, REM

JEL Classifications: E5, E52, E51

\section{Introduction}

Theoretically, the effect of policy transmission through the exchange rate channel (ERC) is studied widely, but there is no consensus. Most studies show a positive relationship between a more competitive currency (undervalued local currency) and growth in emerging markets (Bleaney \& Greenaway, 2001; Cottani, Cavallo, \& Khan, 1990; Dollar, 1992; P Gala, 2007; Paulo Gala \& Libanio, 2009; Ghura \& Grennes, 1993; Glüzmann, Levy-Yeyati, \& Sturzenegger, 2012; Levy-Yeyati, Sturzenegger, \& Gluzmann, 2013; Loayza, Fajnzylber, \& Calderon, 2005; Rodrik, 2008; Vaz \& Baer, 2014). Some theoretical arguments are used to support this empirical relationship. Extroverted policies, expressed in the form of currency devaluation, in East Asian countries encourage foreign trade and promote economic growth, while introverted policies, expressed in overvalued currencies, used in Latin America and Africa, have hindered growth. (Cottani et al., 1990; Dollar, 1992). Paulo Gala \& Libânio (2009) argue that a currency that is undervalued is good for growth because it promotes industrial sector transactions in a nation's economy. In contrast, Razin \& Collins (1997) point to a non-linear relationship between exchange rates and the growth rate of an emerging country. First, exchange rates can affect domestic and foreign investment, accelerating the process of capital accumulation for the economy and thereby, affecting growth. In addition, the exchange rate impact on foreign trade improves the competitiveness of countries around the world, helping the economy grow. However, in the long term, maintaining a high exchange rate policy will increase import prices. The rising inflation will create pressure on money markets and commodity markets, psychological pressure, which will in turn inhibit economic growth. In addition, there were some cases, such as those observed by Mengesha \& Holmes (2013), who found no evidence of the existence of exchange rate channels. However, they found the existence of ERC in the illegal foreign exchange rate market. Most developing countries have strong intervention policies by central banks in the foreign exchange market and their economies have poor links with international financial markets, therefore ERC is weak or even non-existent (Clements et al., 2001; Mishra \& Montiel, 2013). Uganda, Czech Republic, Hungary, Poland are examples of this (Creel \& Levasseur, 2005). Therefore, the evaluation of the effectiveness of monetary policy transmission through the exchange rate channel has many research meanings. 
Economic development and deeper integration among ASEAN countries in regards to exchange rates on the economy are extremely important because it has an impact on domestic market prices, trade balance as well as national output. Therefore, the role of the exchange rate has become more and more prominent. Its impact on economic growth is a matter of concern to many countries, including Vietnam and emerging countries in the ASEAN region. However, after a review of studies published in mainstream journals, we did not find any literature on the impact of exchange rates on economic growth in this region's countries.

\section{Theoretical Basis}

\subsection{Theoretical Basis}

For an open economy, changes in short -term interest rates also affect the economy through the exchange rate channel. In emerging countries with underdeveloped financial markets, the exchange rate channel is an important channel of monetary policy management for the central bank (Demir, 2014; Golinelli \& Rovelli, 2002). For the exchange rate channel to be effective, it is necessary to have an exchange rate mechanism with a certain degree of flexibility, combined with high elasticity of import and export goods with changes in prices. In the floating exchange rate mechanism, loosening monetary policy will cause the domestic currency to depreciate through the impact of interest rate differences with foreign currencies. The depreciation of the domestic currency reduces the demand for imported goods, all the while boosting demand for exports, since domestic goods become relatively cheaper than foreign goods. This leads to an increase in spending on domestic goods and an increase in aggregate demand (Pennings, Ramayandi, \& Tang, 2015).

The transmission process is as follows:

$$
M \uparrow \rightarrow i \uparrow \rightarrow E x \uparrow \rightarrow \text { Export } \uparrow, \text { Import } \downarrow \rightarrow Y \uparrow
$$

Where $\mathrm{M}$ is the money supply, $i$ is the interest rate, Ex is the exchange rate (domestic/foreign currency volume), Export is export value, Import is import value, is total output.

In a small and open economy with a flexible exchange rate mechanism, changing exchange rates also affect total supply (Cwik, Müller, \& Wolters, 2011). When the central bank loosens monetary policy, the depreciating local currency will increase the price of imported goods, directly increasing inflation. In addition, higher import prices lead to increased production costs, affecting the margins of businesses and reducing total supply (Faust \& Rogers, 2003; Kierzenkowski, 2005). The transmission process is as follows:

$$
M \uparrow \rightarrow i \downarrow \rightarrow E x \uparrow \rightarrow P \uparrow \rightarrow Y \downarrow
$$

Where $M$ is the money supply, $i$ is the interest rate, $E x$ is the exchange rate (domestic/foreign currency amount), $P$ is the price level of imported goods for domestic production, $Y$ is the total output.

Changing exchange rates also affect the balance sheet of the business. When economic entities maintain a state of more or less stable exchange rates on the balance sheet, the change of exchange rate will affect the net value of entities, thereby affecting the financial status of these entities (Bjørnland, 2009). In the case of emerging market countries, which usually play the role of debt-holders to other countries, the depreciation of the domestic currency means that the debt burden of entities in the economy will also increase. This creates somewhat overwhelming effects relative to price changes (Karasoy, Kunter, \& Us, 2005). This further affects the consumption, investment and borrowing behaviour of entities, thereby changing the output of the economy.

\subsection{Model}

\section{Real effective exchange rate}

Exchange rate measures the value of one currency compared to the value of another currency. Accordingly, one currency will play the role as the base currency and the other is the valuation currency, in which the value of the base currency is one unit. Except in a few instances where the nominal exchange rate is used in place of the real exchange rate, economists will use the effective exchange rate to compare currencies between two counties. The effective exchange rate compares the price of a good in a country against the same good in a foreign country. The following formula relays this relationship:

$$
\mathrm{REER}=\mathrm{E} \cdot \frac{P *}{P}
$$

In which REER is the real exchange rate, $\mathrm{E}$ is the nominal exchange rate, $\mathrm{P} *$ is the foreign general price index, $\mathrm{P}$ is the domestic common price index. Therefore an increase in E and REER implies a decrease in the value of the local currency.

A number of arguments support the use of real exchange rate instead of the nominal exchange rate in estimating the 
equilibrium exchange rate. The arguments are as following:

- Consumption decisions and production decisions are often made on the basis of real value rather than nominal value (Stein, 1998).

- Most countries, especially developing countries and transition economies, apply a fixed exchange rate policy with a constant nominal exchange rate or are based on one or several large baskets of currencies. Therefore, we will analyze very little if we study only the volatility of the nominal exchange rate.

- Some studies suggest that once the real equilibrium exchange rate has been found, it is easy to calculate the nominal equilibrium exchange rate.

In addition to the bilateral exchange rate formula as shown above, some researchers will use the multilateral effective exchange rate. This rate is used when considering multiple commercial partners and is calculated on the weighted average. The formula is calculated as follows:

$$
\begin{aligned}
& \text { REER }=\sum \beta_{i} \times E i \times \frac{P i^{*}}{P} \\
& \beta_{i}=\frac{E X_{i}+I M_{i}}{E X+I M}
\end{aligned}
$$

$\mathrm{P}_{\mathrm{i}}^{*}$ : is the general price index of country $\mathrm{i}, \beta$ is the proportion of trade with country $i$, EX and IM is the value of exports and imports.

In experimental studies, the research team used the real multilateral effective exchange to measure the impact of the real effective exchange rate on the economic growth rate, denoted as REER.

\section{Model}

In many studies about the relationship between the effective exchange rate and the economic growth rate, the growth rate GDP and the effective exchange rate are the metrics compared. In this study, the team of researchers will select the model used by Rodrik (2008). The model explained the relationship between the real effective exchange rate and the economic growth rate, particularly in countries which have low income and average income over the world (below $6,000 \mathrm{USD} /$ person/year). This impact of the real effective exchange rate on the economic growth rate is explained by Rodrik (2008), through the study of the development of foreign trade in developing countries. The model is as follows:

$$
\mathrm{G}_{\mathrm{it}}=\alpha+\beta \operatorname{lnGDPC} C_{i t-1}+\delta \ln U N D E R V A L_{i t}+f i+f t+u_{i t}
$$

Inside:

$\mathbf{G}_{\mathrm{it}}:$ the growth of the national GDP, in year $\mathrm{t}$ ith

GDPC $_{\text {it-1: }}$ : income per capita of the ith country $(t-1)$.

According to Barro (1989), people are considered to be key to leading research and creating new products or ideas. Therefore, in the countries where people are focused on innovation, income is improved. This is considered as the premise under which the economy can grow faster in the future. This is the same principle that was used by researchers on economic growth, including Rodrik (2008). Accordingly, the human factor or per capita income plays a special role in most economic growth models.

$\mathbf{f}_{\mathbf{t}}$ : the fixed factor of each time period

$\mathbf{f}_{\mathbf{i}}$ : the fixed factor of each country

UNDERVAL $L_{i t}$ : The value index, determined through the function:

$$
\ln U N D E R V A L_{i t}=\ln \text { REER }_{i^{-}} \ln \widehat{R E E R_{\text {it }}}
$$

Inside:

REER $_{\mathrm{it}}$ : the multilateral effective exchange rate of country $\mathrm{i}$ in year $\mathrm{t}$

$\widehat{R E E R_{\mathrm{it}}}$ : predictive value of the model's effective multilateral exchange rate:

$$
\ln \operatorname{REER}_{\mathrm{it}}=\alpha+\beta \ln \mathrm{GDPC}_{\mathrm{it}}+\mathbf{f}_{\mathrm{t}}+\boldsymbol{u}_{i t}
$$

Balassa's model (3) "Balassa, B, (1964)" explains the fluctuation of real effective exchange rates in the long run, since the purchasing power parity does not exist in the long term. In other words, the real effective exchange rate, in the long run, will change. The classical theory of purchasing power parity assumes that all goods are capable of being exchanged through trade between countries around the world. However, goods in the economy are classified into two categories: exchangeable and non-exchangeable goods. When the prices of tradable goods change, the nominal exchange rate also 
changes to conform to the theory of purchasing power parity. The nominal exchange rate does not reflect the price change of non-exchangeable goods, so it does not reflect the relative price change between the two commodity baskets in the two countries.

The Balassa Samuelson model assumes that a country's growth is largely based on an increase in labour productivity in the modern manufacturing sector. Meanwhile, labour productivity in traditional manufacturing areas and services has contributed to little change. We assume that human resources can only be transferred across economic sectors without being able to move around the world. Therefore, as labour productivity increases in the field of modern production, salaries in this field also increase. To keep the balance, salaries in traditional fields and services also increase.

Accordingly, in developed countries with advanced science and technology, modern production, traditional production and services which are also developed, salaries in traditional manufacturing and services are higher than those of developing countries. In other words, the living standards of the people (per capita income) in these countries are higher. Consequently, if comparing a country's basket of goods, developed countries will have higher prices than developing countries or in other words, exchange rates in developed countries tend to be set at higher prices. Therefore, to make sense in the long term, Rodrik (2008) adjusted the effective exchange rate according to the effect of Balassa (1964) by regressing the per capita income variable (GDPC).

In this formula, according to the theory of Balassa (1964) that Rodrik (2008) explained, model (2) is expected to be negative. That is, the richer countries are, the higher the exchange rate tends to be. However, in ASEAN countries the author expects (2) to be positive because the country is still in the group of developing countries. The higher the income, the higher the exchange will be, i.e. the local currency the more undervalued.

\section{Methodology and Database}

\subsection{Database}

Secondary data on variables in the research model was collected from the author from reliable sources, namely:

G: GDP growth rate of 5 countries in the period of 1989-2018 is taken from the official records of Worldbank: Vietnam, Indonesia, Singapore, Philippines, Malaysia.

GDPC $_{\mathrm{it}-1}$ : per capita income of 5 countries during 1989-2018 is taken from the official record of World bank

REER $_{\mathrm{it}}$ : the multilateral effective exchange rate of 5 countries for the period of 1989-2018 is taken from the official record of World bank

The data table includes 5 countries and data is collected annually from 1989-2018, therefore this study sample includes 150 observations and meets the requirements of suitability.

\subsection{Methodology}

Research model (1) is proposed on the basis of the research work of the effect of real exchange rate on the economic growth rate in countries around the world. The author uses estimation methods for data such as fixed effects (Fixed Effects), random effects (Random Effects), and estimated general minimum squares Prais-Winsten (PCSE) to overcome the variance change and autocorrelation in order to build a model to measure the effect of real effective multilateral exchange rates on the growth rate using State software with Panel Data.

Model (1) is estimated by the methods of estimating table data. Specifically, on the data, consider patterned form:

$$
y_{i t}=B_{1}+B_{2} X_{i t}+a Z_{i t}+u_{i t}
$$

Inside: $\mathrm{Z}$ is the variable used to represent specific characteristics (here we consider the specific characteristics of the country i). Due to the impact of specific characteristic $Z_{\mathrm{i}}$ on the model, it will form the different models on the table data.

- If the effect is not calculated and is random, we use the REM model.

- On the contrary, if the calculated effect is determined, we use the Fixed effects model.

\section{- $\quad$ Fixed effects model (FEM)}

Assuming each entity has its own characteristics that can affect the explanatory variables, Fixed effects analyzes this correlation between the remainder of each entity and explanatory variables that control and separate the effect of individual characteristics (constant over time) from explanatory variables, so that we can estimate the net effects of the explanatory variables on dependent variables.

Estimated usage model:

$$
Y_{i t}=C_{i}+B X_{i t}+u_{i t}
$$

Inside: 
- $Y_{i t}$ : the dependent variable with i: National No i, t: time (what quarter?).

- $X_{i t}$ : independent variables

- $C_{i}$ : blocking factor for each observed entity

- $B$ : slope

- $u_{i t}$ : remainder

The above model has added the i-index to the C-blocking factor to differentiate the blocking coefficient of each different country, this difference may be due to different characteristics of each country or due to the difference in management policies, national activities.

\section{- $\quad$ Random Effects Model (random effects -REM)}

The difference between the REM the fixed effect model is shown in the variation between entities. If the variation between entities is correlated with the independent variable - the explanatory variable in the fixed effects model, then in the REM the variation between the entities is assumed to be random and to be not correlated with the explanatory variables.

Therefore, if the difference in entities affects the dependent variable, REM is preferable to FEM. In particular, the remainder of each entity (not correlated with the explanatory variable) is considered a new explanatory variable.

The basic idea of a random effect model also starts from the model:

$$
Y_{i t}=C_{i}+B X_{i t}+u_{i t}
$$

Instead of the FEM model, $\mathrm{C}_{\mathrm{i}}$ is fixed, in REM it is assumed that it is a random variable with an average of $\mathrm{C}$ and a blocking coefficient value described as follows:

$C_{i}=C+\varepsilon_{i}$ with $(\mathrm{i}=1,2,3 \ldots \mathrm{n})$

$\varepsilon_{i t}$ is a random error with a mean of 0 and a variance constant

Instead of the model we have:

$$
Y_{i t}=C+B X_{i t}+u_{i t}+\varepsilon_{i}
$$

Or

$$
Y_{i t}=C+B X_{i t}+w_{i t} \text { with } w_{i t}=\varepsilon_{i}+u_{i t}
$$

$\varepsilon_{i}$ : component error of different objects ( specific characteristics of each country)

$u_{i t}$ : Differences of other combined components of both characteristics by each object and by country.

In general, REM or FEM is better for research, depending on the assumption of the correlation between $\varepsilon_{i}$ and explanatory variables X. If the assumption is not correlated, The Fixed effects model is more appropriate and opposite. I Hausman test is one of the methods to choose a REM or FEM.

\section{- Comparison between REM or FEM}

Use the Hausman test:

$\mathrm{H}_{\mathrm{o}}: \operatorname{Cov}\left(X_{i t}, u_{i}\right)=0$ ( random effects)

$\mathrm{H}_{1}: \operatorname{Cov}\left(X_{i t}, u_{i}\right) \neq 0$ ( fixed effects)

- If p-value $<\alpha$, then reject hypothesis $\mathrm{H}_{0}$.

- If p-value $>\alpha$, accept hypothesis $\mathrm{H}_{0}$.

\section{- Required tests}

- The Wald test is used to test variance changes across entities.

$\mathrm{H}_{0}$ : the variance of a constant variable

For p-value $>0.05$, the hypothesis $\mathrm{H}_{0}$ is accepted.

- Wooldridge test is used to check autocorrelation in table data.

$\mathrm{H}_{0}$ : There is no correlation present.

For $\mathrm{p}$-value $>0.05$, the hypothesis $\mathrm{H}_{0}$ is accepted.

- If the selected model has autocorrelation or variance changes through entities, the author uses the Prais-Winsten method to overcome this phenomenon. 


\section{Empirical Results and Discussion}

\subsection{Description of Statistical Data}

Table 4.1 shows that per capita income in the period 1985-2015 of Vietnam, Indonesia, Singapore, Philippines, Malaysia has an average value of USD 7,321/person/ year. The country with the highest per capita income was Singapore in 2014, reaching 56,007 USD/person/year. The country with the lowest per capita income was Vietnam, in 1989 , with an income of $97.15 \mathrm{USD} /$ person/year.

Table 4.1. Descriptive statistics data

\begin{tabular}{|c|c|c|c|c|c|}
\hline Variable & Obs & Mean & Std.Dev & Min & Max \\
\hline REER & 155 & 107.803 & 43.45404 & 51.13 & 465.87 \\
\hline GDPC & 155 & 7321.363 & 12528.73 & 97.15788 & 56007.29 \\
\hline G & 155 & 0.0553328 & 0.035744 & -0.1312672 & 0.1524038 \\
\hline
\end{tabular}

Source: Calculation results from STATA 12.0 software

In addition, the economic growth rate in the period 1985-2015 of Vietnam, Indonesia, Singapore, Philippines and Malaysia has an average value of 5.53\%/year. The country with the highest economic growth rate was Singapore in 2010, reaching 15.24\%/year. The country with the lowest economic growth rate was Indonesia, in 1998, with the economic growth rate of $-13 \% /$ year.

\subsection{Regression Results of the Model (3)}

Table 4.2. Results of model regression coefficients (3)

\begin{tabular}{rrrrr}
\hline LnREER & Coef. & Std.err. & t & P>t \\
\hline lnGDPC & -0.0049891 & 0.0133668 & -0.37 & 0.709 \\
_cons & 4.678632 & 0.1056427 & 44.29 & 0.000 \\
\hline
\end{tabular}

Source: Calculation results from STATA 12.0 software

Table 4.2 estimates the correlation between variables in the model (3) of Vietnam, Indonesia, Singapore, the Philippines, Malaysia in the period $1985-2015$ by the least-squares regression method (OLS). After regressing the model, the authors take the residuals in the above estimate to use as a representation of the change of the actual multilateral effective exchange rate compared to the average effective rate. This variable is denoted by $\mathrm{r}$ or (Ln UNDERVAL).

\subsection{Matrix of the Correlation Coefficient}

Table 4.3. Correlation coefficient matrix of variables in model 1

\begin{tabular}{r|rrr}
\hline & G & LnGDPC.L1 & \\
\hline G & 1 & & \\
LnGDPC.L1 & 0.0129 & 1 & \\
$\mathrm{r}$ & 0.1031 & 0.0052 & 1 \\
\hline
\end{tabular}

Source: Calculation results from STATA 12.0 software

Table 4.3 shows that the correlation coefficient between the change in the effective multilateral exchange rate and the average effective exchange rate has a positive correlation with the GDP growth rate and per capita income of Vietnam, Indonesia, Singapore, Philippines, Malaysia. To see this relationship clearly, the authors continue to work model (1) by FEM, REM methods.

\subsection{Fixed Effects Method -FE}

Table 4.4. Results of regression analysis of model 1 by FE method

\begin{tabular}{|c|c|c|c|c|}
\hline Variable & Coef. & Std.err. & $\mathbf{t}$ & $P>t$ \\
\hline LnGDP.L1 & -0.0085847 & 0.0042383 & -2.03 & 0.045 \\
\hline $\mathrm{r}$ & 0.0129948 & 0.0116663 & 1.11 & 0.267 \\
\hline cons & 0.1237591 & 0.0328761 & 3.76 & 0.000 \\
\hline
\end{tabular}

Source: Calculation results from STATA 12.0 software

The estimation results of the model (1) by the fixed effects method show that the per capita income variables of the previous year $\left(\operatorname{lnGDPC}_{\mathrm{it}-1}\right)$ have statistically significant effects and changes of the effective multilateral effective exchange rate compared to the average effective exchange rate (ln UNDERVAL $L_{\text {it }}$ ) has no impact. The coefficient is not statistically significant to the economic growth rate in the sample. The authors continue to estimate model 1 with REM method. 


\subsection{Random Effects Method-RE}

Table 4.5. Results of regression analysis of model 1 by RE method

\begin{tabular}{rrrrr}
\hline Variable & Coef. & Std.err. & t & P>t \\
\hline LnGDP.L1 & 0.0002773 & 0.0018436 & 0.15 & 0.880 \\
r & 0.0143543 & 0.0114292 & 1.26 & 0.209 \\
cons & 0.055308 & 0.0145106 & 3.81 & 0.000 \\
\hline
\end{tabular}

Source: Calculation results from STATA 12.0 software

The estimation results of the model (1) by the random effects method show the income per capita of the previous year $\left(\operatorname{lnGDPC}_{\mathrm{it}-1}\right)$ and the change of the real effective multilateral exchange rate in comparison with the average effective exchange rate (ln UNDERVAL $\mathrm{H}_{\mathrm{it}}$ ). There is no statistically significant effect on the economic growth rate in the sample. The authors continue to use the Hausman test to select the suitability of the two models.

4.6 Compliance Test Between Two Models

Table 4.6. Compliance test results between two models

\begin{tabular}{ll}
\hline Test & $\mathrm{H}_{0}:$ difference in coefficients not systematic \\
& chi2(2) $=(\mathrm{b}-\mathrm{B})^{\prime}\left[\left(\mathrm{V}_{-} \mathrm{b}-\mathrm{V}_{-} \mathrm{B}\right)^{\wedge}(-1)\right](\mathrm{b}-\mathrm{B})$ \\
& $=76.75$ \\
& Prob $>$ chi $2=0.0000$
\end{tabular}

Source: Calculation results from STATA 12.0 software

To select the appropriate model, the author conducted the Hausman test. With the hypothesis:

$$
\begin{aligned}
& \mathrm{H}_{\mathrm{o}}: \operatorname{Cov}\left(X_{i t}, u_{i}\right)=0 \text { ( random effects) } \\
& \mathrm{H}_{1}: \operatorname{Cov}\left(X_{i t}, u_{i}\right) \neq 0 \text { ( fixed effects) }
\end{aligned}
$$

p-value $=0,0000<$ significance level $5 \%$. Therefore we accept the hypothesis $H_{1}$, i.e. the method of fixed effects is more appropriate to estimate the model (1).

\subsection{Test of the Variance of Model Change (1)}

Table 4.7. Results of the testing variance of models (1)

\begin{tabular}{ll}
\hline $\mathrm{H}_{0}:$ & $\operatorname{sigma}(\mathrm{i})^{\wedge} 2=\operatorname{sigma}(\mathrm{i})^{\wedge} 2$ for all $\mathrm{i}$ \\
\hline chi2 $(5)=$ & 84.04 \\
Prob $>$ chi $2=$ & 0.0000 \\
\hline Source: $\quad$ Calculation results from & STATA 12.0 software
\end{tabular}

To test the variance change phenomenon through the model's entities (1), the authors conducted the Wald test. With the hypothesis:

- $\mathrm{H}_{0}$ : the variance of a constant variable

- $\mathrm{H}_{1}$ : the variance of a changed variable

$\mathrm{P}$-value $=0,000<$ significance level $5 \%$. Therefore the hypothesis $\mathrm{H}_{1}$ is accepted: the variance of a changed variable.

4.8 Autocorrelation Test of the Model (1)

Table 4.8. Results of the autocorrelation test of the model (1)

\begin{tabular}{ll}
\hline $\mathrm{H}_{0}:$ & No first-order autocorrelation in panel data \\
\hline $\mathrm{F}(1,4)=$ & 33.830 \\
Prob $>\mathrm{F}=$ & 0.0043 \\
\hline
\end{tabular}

Source: Calculation results from STATA 12.0 software

To test the variance change phenomenon through the entities of the model (1), he authors conducted a Wooldridge test. With the hypothesis:

- $\mathrm{H}_{0}$ : There is no correlation present. 
- $\mathrm{H}_{1}$ : There is a similar correlation.

P-value $=0,0043<5 \%$. significance level. Therefore, we have the basis to reject the hypothesis $\mathrm{H}_{0}$. There is the autocorrelation phenomenon in the model at the $5 \%$ significance level.

Thus, the model (1) is estimated by the fixed effects method with the variance change phenomenon and autocorrelation. To overcome these two phenomena, the authors conducted a re-estimation of the model (1) by the Prais-Winsten (PCSE) method. The estimated results are as follows:

4.9 Estimating the Model Regression Coefficient(1) by the Prais-Winsten (PCSE) Method

Table 4.9. Estimation results of the model regression coefficient(1) by the Prais-Winsten method

\begin{tabular}{rrrrr}
\hline Variable & Coef. & Std.err. & t & P>t \\
\hline $\mathrm{r}$ & 0.020944 & 0.0101658 & 2.06 & 0.039 \\
LnGDP.L1 & -0.0003949 & 0.0029567 & -0.13 & 0.894 \\
_cons & 0.0596909 & 0.0214547 & 2.78 & 0.005 \\
\hline
\end{tabular}

Source: Calculation results from STATA 12.0 software

The estimated results show that the regression coefficient of the per capita income variables last year $\left(\operatorname{lnGDPC}_{\mathrm{it}-1}\right)$ of Vietnam, Indonesia, Singapore, Philippines, and Malaysia in the period 1985-2015 did not have a statistically significant impact on economic growth rates. In contrast, the change of the multilateral effective exchange rate compared to the average effective exchange rate (ln UNDERVAL $L_{\text {it }}$ ) has a statistically significant effect on the economic growth rates of the 5 countries.

The specific effect of the change in the actual multilateral effective exchange rate compared to the average effective exchange rate (ln UNDERVAL ${ }_{\mathrm{it}}$ ) on the economic growth rates of the 5 countries is as follows:

The regression coefficient of the variable (ln UNDERVAL $L_{i t}$ ) with a value of 0.020944 has a positive value $(+)$. This result is in line with the initial mark expectation, which shows that when the actual multilateral effective exchange rate compared to the expected effective multilateral exchange rate (ln UNDERVAL $\mathrm{L}_{\mathrm{it}}$ ) increases $1 \%$, it will have a positive impact and can cause economic growth of a country to increase by $2.09 \%$. Thus, the author's research results are consistent with those of Rodrik (2008), which means that there is a positive relationship between the effective exchange rate and the economic growth rate in developing countries, including Vietnam.

\section{Conclusion}

Studying and establishing a research model that reflects the relationship between the multilateral effective exchange rate and the economic growth rate of 5 countries like Vietnam, Indonesia, Singapore, Philippines, Malaysia based on studies that have been done in the world. To estimate this model, the authors used the method of estimating data tables Fixed effects and Random effects. The Hausman test shows that the model estimated by the Fixed effects method is more suitable than the REM. However, variance change and autocorrelation happened in the estimation model by Fixed effects method. The authors overcome this phenomenon by Prais-Winsten (PCSE) method. The final model shows that a $1 \%$ increase in the multilateral effective exchange rate $\left(\ln \mathrm{UNDERVAL}_{\text {it }}\right)$ will have a positive impact on the average economic growth of the 5 countries, increasing by $2.09 \%$.

Through the empirical research results, ASEAN countries should rely on effective exchange rates to evaluate the economy as well as the suitability of the exchange rate. Real effective exchange rates are adjusted based on the inflation rate so that it will reflect the condition of the economy and the level of stability of macroeconomy. At the same time, the real effective exchange rate needs to be placed in relation to the concept of a basket of currencies, and the government adjusted the USD in the margin allowed but it is necessary to compare with other types of the effective exchange rate in the basket of currencies.

In addition, according to the theory of Balassa (1964), the effective exchange rate is also adjusted for non-exchangeable and exchangeable goods between two countries with foreign trade relations. In this way, the effective exchange rate just goes into the market and just reflects all elements of commodity prices between the two countries.

However, no matter how the exchange rate is calculated, the role of macro managers in managing the exchange rate can be considered. Exchange rate mechanism of matching most to Vietnam is still a flexible exchange rate, providing flexibility in relation to supply and demand with the administration so the state in which we are applying. However, the goal of the management of the government should be greater clarity and accuracy. The floating exchange rate policy has helped manage many countries in the current period, especially developing countries. For the ASEAN countries, it is necessary to focus on building a flexible exchange rate mechanism, but to proceed to a " target exchange rate". This rate 
is understood as the level of the exchange rate that satisfies each nation's development goals in a certain period. Accordingly, the level of depreciation or appreciation of the local currency will be adjusted to suit the economy's goals.

\section{References}

Balassa, B. (1964). The Purchasing-Power Parity Doctrine: A Reappraisal. Journal of Political Economy, 72(6), 584-596. https://doi.org/10.1086/258965

Barro, R. J. (1989). Economic Growth in a Cross Section of Countries. National Bureau of Economic Research Working Paper Series, No. 3120. https://doi.org/10.3386/w3120

Bjørnland, H. C. (2009). Monetary policy and exchange rate overshooting: Dornbusch was right after all. Journal of International Economics, 79(1), 64-77. https://doi.org/10.1016/j.jinteco.2009.06.003

Bleaney, M., \& Greenaway, D. (2001). The impact of terms of trade and real exchange rate volatility on investment and growth in sub-Saharan Africa. Journal of Development Economics, 65(2), 491-500. https://doi.org/10.1016/s0304-3878(01)00147-x

Clements, B. J., Kontolemis G., Z., \& Levy, J. V. F. (2001). Monetary Policy Under EMU Differences in the Transition Mechanism? IMF Working Papers, 01 (102), 1. https://doi.org/10.5089/9781451852615.001

Cottani, J. A., Cavallo, D. F., \& Khan, M. S. (1990). Real Exchange Rate Behavior and Economic Performance in LDCs. Economic Development and Cultural Change, 39(1), 61-76. https://doi.org/10.1086/451853

Creel, J., \& Levasseur, S. (2005). Monetary Policy Transmission Mechanisms in the CEECs: How Important are the Differences with the Euro Area? SSRN Electronic Journal. https://doi.org/10.2139/ssrn.826284

Cwik, T., Müller, G. J., \& Wolters, M. H. (2011). Does trade integration alter monetary policy transmission? Journal of Economic Dynamics and Control, 35(4), 545-564. https://doi.org/10.1016/j.jedc.2010.11.006

Demir, İ. (2014). Monetary policy responses to the exchange rate: Empirical evidence from the ECB. Economic Modelling, 39, 63-70. https://doi.org/10.1016/j.econmod.2014.02.024

Dollar, D. (1992). Outward-Oriented Developing Economies Really Do Grow More Rapidly: Evidence from 95 LDCs, 1976-1985. Economic Development and Cultural Change, 40(3), 523-544. https://doi.org/10.1086/451959

Faust, J., \& Rogers, J. (2003). Monetary policy's role in exchange rate behavior. Journal of Monetary Economics, 50(7), 1403-1424. Retrieved from https://econpapers.repec.org/RePEc:eee:moneco:v:50:y:2003:i:7:p:1403-1424

Gala, P. (2007). Real exchange rate levels and economic development: theoretical analysis and econometric evidence. Cambridge Journal of Economics, 32(2), 273-288. https://doi.org/10.1093/cje/bem042

Gala, P., \& Libânio, G. (2009). Exchange rate policies, patterns of specialization and economic development: theory and evidence in developing countries.

Ghura, D., \& Grennes, T. J. (1993). The real exchange rate and macroeconomic performance in Sub-Saharan Africa. Journal of Development Economics, 42(1), 155-174. https://doi.org/10.1016/0304-3878(93)90077-z

Glüzmann, P. A., Levy-Yeyati, E., \& Sturzenegger, F. (2012). Exchange rate undervaluation and economic growth: Díaz Alejandro (1965) revisited. Economics Letters, 117(3), 666-672. https://doi.org/10.1016/j.econlet.2012.07.022

Golinelli, R., \& Rovelli, R. (2002). Monetary Policy Transmission, Interest Rate Rules and Inflation Targeting in Three Transition Countries. SSRN Electronic Journal. https://doi.org/10.2139/ssrn.299409

Karasoy, A., Kunter, K., \& Us, V. (2005). Monetary transmission mechanism in Turkey under free float using a small-scale macroeconomic model. Economic Modelling, 22(6), 1064-1073. https://doi.org/10.1016/j.econmod.2005.07.001

Kierzenkowski, R. (2005). The multi-regime bank lending channel and the effectiveness of the Polish monetary policy transmission during transition. Journal of Comparative Economics, 33(1), 1-24.

https://doi.org/10.1016/j.jce.2004.09.001

Levy-Yeyati, E., Sturzenegger, F., \& Gluzmann, P. A. (2013). Fear of appreciation. Journal of Development Economics, 101, 233-247. https://doi.org/10.1016/j.jdeveco.2012.11.008

Loayza, N., Fajnzylber, P., \& Calderon, C. (2005). Economic Growth in Latin America and the Caribbean. The World Bank. https://doi.org/10.1596/0-8213-6091-4

Mengesha, L. G., \& Holmes, M. J. (2013). Monetary policy and its transmission mechanisms in Eritrea. Journal of Policy Modeling, 35(5), 766-780. https://doi.org/10.1016/j.jpolmod.2013.06.001

Mishra, P., \& Montiel, P. (2013). How effective is monetary transmission in low-income countries? A survey of the 
empirical evidence. Economic Systems, 37(2), 187-216. https://doi.org/10.1016/j.ecosys.2012.12.001

Pennings, S., Ramayandi, A., \& Tang, H. C. (2015). The impact of monetary policy on financial markets in small open economies: More or less effective during the global financial crisis? Journal of Macroeconomics, 44, 60-70. https://doi.org/10.1016/j.jmacro.2015.01.001

Razin, O., \& Collins, S. (1997). Real Exchange Rate Misalignments and Growth. National Bureau of Economic Research. https://doi.org/10.3386/w6174

Rodrik, D. (2008). The real exchange rate and economic growth. Brookings Papers on Economic Activity, 2, 365-412.

Stein, J. L. (1998). The Natural Real Exchange Rate of the United States Dollar, and Determinants of Capital Flows. Fundamental Determinants of Exchange Rates. Oxford University Press. https://doi.org/10.1093/0198293062.003.0002

Vaz, P. H., \& Baer, W. (2014). Real exchange rate and manufacturing growth in Latin America. Latin American Economic Review, 23(1). https://doi.org/10.1007/s40503-014-0002-6

\section{Copyrights}

Copyright for this article is retained by the author(s), with first publication rights granted to the journal.

This is an open-access article distributed under the terms and conditions of the Creative Commons Attribution license which permits unrestricted use, distribution, and reproduction in any medium, provided the original work is properly cited. 